\title{
HLA antigen frequencies in flax byssinosis patients
}

\author{
D. Middleton, J. S. LOGAN, B. P. MAgenNis, AND S. D. Nelson \\ From the Transplantation and Immunology Laboratory, Belfast City Hospital, and the Royal Victoria \\ Hospital, Belfast
}

ABSTRACT Not all workers exposed to flax dust contract byssinosis. It is not known what determines susceptibility or insusceptibility. This study is an attempt to establish whether the incidence of histocompatibility antigens is involved in susceptibility to the disease. Forty patients suffering from flax byssinosis were tissue-typed for HLA-A and -B antigens. HLA-B27 was significantly more common in the patients $(22.5 \%)$ than in the controls $(5.5 \%) ; P=0.029$ after correction for the number of antigens compared. HLA-A11 was present in twelve patients $(30 \%)$ compared with $14 \%$ in the controls; after correction for the number of comparisons, this is not a statistically significant increase. Because HLA-B27, though significantly more common in flax byssinosis, is not necessary for its occurrence $(77.5 \%$ of our patients did not have it), it is possible that the increase in the frequency of HLA-B27 is attributable to an association with other genes, perhaps those regulating the immune response or coding for antigens at other HLA loci.

Flax byssinosis is a disabling disease of the lungs occurring in workers who prepare flax for spinning. It also occurs in those handling the spun yarn when it is dry and, though much less frequently, in weavers of linen. It has affected both those working flax by hand and those engaged in mechanical spinning (Ramazzini, 1705; Malcolm, 1856; Smiley, 1951, 1956; Logan, 1959; Carey et al., 1965). The diagnosis depends on the patient having a chronic chest disease of wheezy emphysematous type, on there being a history of occupational exposure to flax dust and on the occurrence of the Monday exacerbation. When a worker is withdrawn from exposure to the dust, either briefly at the weekend or for a longer time at the annual summer holiday, the symptoms and distress are less. When he or she returns to work the distress is marked and worse on the first day of exposure and, at least in the earlier stages, the other days of the week are not as bad as Monday.

While many workers contract the disease, some, though exposed to the same concentration of flax dust, are not affected. There seems therefore to be some individual susceptibility involved in the occurrence of the disease. While other chest diseases can co-exist with flax byssinosis and can make the total chest disability worse, clinical experience does

Address for correspondence: Dr J. S. Logan, Royal Victoria Hospital, Grosvenor Road, Belfast, Northern Ireland.

Received for publication 11 May 1978

Accepted for publication 28 July 1978 not indicate that byssinosis is occasioned by preexisting asthma, tuberculosis, smoking or snufftaking.

It has been established that there are unusual distributions of certain histocompatibility (HLA) antigens in patients with certain diseases (Svejgaard et al., 1975). Our study was designed to investigate the incidence of HLA antigens in patients who have developed flax byssinosis, in order to see if any of the antigens are involved in susceptibility to the disease. It may be argued that, because inhalation of flax dust is an abnormal experience, it is normal to develop byssinosis, rather than to fail to react to the flax dust. For our present purpose it is not necessary to debate this point. We are concerned with the identification of characteristics associated with susceptibility to the disease, partly in order to advance knowledge of the genesis of the disease and partly in the hope of advising workers on their safety in the industry.

\section{Patients and methods}

Forty patients suffering from flax byssinosis (mean age 60 years, range 21-85 years) were tissue-typed for HLA-A and -B antigens. Criteria for the inclusion of a patient were as noted above: the existence of a chronic chest disease of wheezy emphysematous type, a history of occupational exposure to flax dust and a history of the Monday exacerbation. Patients with equivocal findings were excluded but no patient with flax byssinosis was excluded because of other 
Table Frequency of HLA antigens in patients with flax byssinosis and in blood donors from Northern Ireland

\begin{tabular}{|c|c|c|c|c|c|c|}
\hline \multirow[t]{2}{*}{$H L A$ antigen } & \multicolumn{2}{|c|}{ Flax byssinosis $(n=40)$} & \multicolumn{2}{|c|}{$N$. Ireland blood donors $(n=200)$} & \multirow[t]{2}{*}{$\chi^{2}$} & \multirow[t]{2}{*}{$\mathbf{P}$} \\
\hline & No. & $\%$ & No. & $\%$ & & \\
\hline $\begin{array}{r}1 \\
2 \\
3 \\
9 \\
10 \\
11 \\
28 \\
29\end{array}$ & $\begin{array}{r}14 \\
21 \\
9 \\
3 \\
2 \\
12 \\
0 \\
2\end{array}$ & $\begin{array}{c}35 \\
52 \cdot 5 \\
22 \cdot 5 \\
7 \cdot 5 \\
5 \\
30 \\
0 \\
5\end{array}$ & $\begin{array}{l}86 \\
91 \\
53 \\
31 \\
20 \\
28 \\
10 \\
16\end{array}$ & $\begin{array}{l}43 \\
45 \cdot 5 \\
26 \cdot 5 \\
15 \cdot 5 \\
10 \\
14 \\
5 \\
8\end{array}$ & 5.046 & $\begin{array}{c}0.0234 \\
(0.491)\end{array}$ \\
\hline $\begin{array}{r}5 \\
7 \\
8 \\
12 \\
13 \\
14 \\
15 \\
17 \\
18 \\
22 \\
27 \\
35 \\
40\end{array}$ & $\begin{array}{r}2 \\
13 \\
10 \\
9 \\
0 \\
3 \\
2 \\
4 \\
3 \\
5 \\
9 \\
4 \\
6\end{array}$ & $\begin{array}{c}5 \\
32 \cdot 5 \\
25 \\
22 \cdot 5 \\
0 \\
7 \cdot 5 \\
5 \\
10 \\
7 \cdot 5 \\
12 \cdot 5 \\
22 \cdot 5 \\
10 \\
15\end{array}$ & $\begin{array}{r}13 \\
67 \\
69 \\
54 \\
5 \\
30 \\
9 \\
18 \\
16 \\
8 \\
11 \\
16 \\
20\end{array}$ & $\begin{array}{c}6 \cdot 5 \\
33 \cdot 5 \\
34 \cdot 5 \\
27 \\
2 \cdot 5 \\
15 \\
4 \cdot 5 \\
9 \\
8 \\
4 \\
5 \cdot 5 \\
8 \\
10\end{array}$ & $10 \cdot 484$ & $\begin{array}{c}0.0014 \\
(0.029)\end{array}$ \\
\hline
\end{tabular}

Only $x^{2}$ values $>4$ are recorded; $P$ values in brackets have been corrected for the number of antigen frequencies compared.

co-existing or previous chest diseases. None of our patients suffered from ankylosing spondylitis or Reiter's syndrome. Two further patients, who were first-degree relatives of patients in the study, were tissue-typed but because of their relationship have not been included in the statistical analysis.

Sera defining the antigens HLA-A1, A2, A3, A9, A10, A11, A28, A29, B5, B7, B8, B12, B13, B14, B15, B17, B18, BW22, B27, BW35 and B40 were either supplied by the National Tissue-Typing Reference Laboratory, Bristol, or were antisera of our own which had been tested for their specificity in other laboratories. Tissue typing was by a twostage microlymphocytotoxicity test (Nelson and Middleton, 1975) and at least three sera were used to define each antigen.

The frequencies of the HLA antigens in the patients were compared with those in 200 blood donors from Northern Ireland. The significance of differences between the two groups was assessed by a Yates' corrected $\chi^{2}$ test.

\section{Results}

The frequency of HLA-A and HLA-B antigens in $\mathbf{4 0}$ patients with flax byssinosis and in the control group is shown in the Table. Only $\chi^{2}$ values greater than four are given.

The frequency of the HLA antigens A11 and B27 differ significantly in patients from their respective frequencies in the control population. HLA-A11 is present in $30.0 \%$ of patients compared with $14 \%$ of normals $(P=0.0234)$ and $\mathrm{B} 27$ in $22.5 \%$ of patients compared with $5.5 \%$ of normals $(P=0.0014)$. The difference for B27 remains significant even after correction for the number of antigen comparisons made $(0.0014 \times 21=0.029)$.

The combination HLA-A11/B27 occurred in two patients $(5 \%)$ but in only one of the blood donors $(0.5 \%)$. This finding is not statistically significant. Neither HLA-A11 nor B27 were found in the two patients who were excluded from the analysis because of sibship with patients in the study.

\section{Discussion}

We have compared the HLA antigen frequency in patients with flax byssinosis with the HLA antigen frequency in blood donors from Northern Ireland. HLA-A11 and B27 had a significantly higher frequency in the patients than in the controls, and the frequency of HLA-B27 was still significantly different after correction for the number of antigens compared.

We recognised that the ideal comparison would be with a group of flax workers who had equal exposure to an equal concentration of flax dust for an equal time. Such quantification of the dose of dust is impossible. Moreover the duration of exposure before developing byssinosis is so variable that, as long as the worker is at work and exposed to dust, it is impossible to say that he or she will not develop byssinosis.

We therefore resorted to a comparison with blood donors drawn from a relatively stable population living in Northern Ireland. Our patients are of an 
older age group than the controls. The relevance of age to HLA antigen distribution is debatable, and Gerkins et al. (1974) have suggested that older people have rather more HLA specificities. However, in our study the average number of antigens in patients and controls was 3.33 and 3.44 respectively.

We are aware of the possibility that bias could have been introduced into our patient group by the inclusion of relatives. People employed in a spinning mill often come from a reasonably settled community living close to the mill and sometimes they are related. However our patients were drawn from several areas of Belfast and from other towns 40-60 miles from Belfast. No members of the same sibship were included in our results and no other relationship was known. Bias may further have been introduced into the patient group because there is some degree of self-selection in patients with flax byssinosis. They are a group who, when they first became affected with symptoms, chose not to leave the industry and thus remained exposed to the dust. Those more alert to the risk and able to get other employment were likely to leave the work immediately the symptoms began. In the latter group the effects of flax dust regressed, the disease did not develop and these individuals were not available to augment and perhaps modify the patient group.

Reports of antigens of the HLA-A locus being associated with diseases have usually been explained by their linkage disequilibrium with an antigen from the HLA-B locus. In our study this does not appear to be the case, as only two of 12 patients with HLAA11 had also HLA-B27. The increased frequency of HLA-B27 is well recognised in ankylosing spondylitis (Brewerton et al., 1973a; Schlosstein et al., 1973), in Reiter's syndrome (Brewerton et al., 1973b) and in other forms of arthritis including juvenile rheumatoid arthritis (Buc et al., 1974). The explanation for the association with ankylosing spondylitis is not known. It may be attributable to an association between genes coding for HLA-B antigens and immune response genes, or it may be that there is molecular mimicry between the HLA-B27 antigen and a microorganism responsible for the onset of ankylosing spondylitis. Direct evidence for the involvement of bacterial infection in ankylosing spondylitis is lacking, although it has been shown that serum from rabbits immunised with Klebsiella bacterial antigen reacted with B27-positive lymphocytes and that serum from rabbits immunised with B27-positive lymphocytes reacted with Klebsiella (Ebringer et al., 1976). If a cross-reaction between B27 and a microorganism is involved in ankylosing spondylitis it would be of interest to investigate whether any similar cross-reactivity is involved in patients with flax byssinosis, because it cannot be assumed that the harmful agent in flax byssinosis is solely flax. The flax may be a vehicle for another agent, fungal, bacterial, or parasitic. However, in our study $77.5 \%$ of the patients with flax byssinosis did not possess HLA-B27 and it is more likely that the increase in the frequency of HLA-B27 was caused by an association with other genes, whether these were regulating the immune response or coding for antigens at other HLA loci.

The best proof of a deviation is always that obtained by studying the deviating antigens in a new patient sample. With the flax-spinning industry so reduced in size and the dust risk diminishing, it will be difficult for us to find new patients and it may be that studies in other countries will be necessary to confirm our results.

While it may be hoped that ultimately, by the use of methods yet to be developed, those people liable to develop byssinosis could be identified at a preemployment examination and excluded from work in the flax industries, tissue-typing does not make this possible at present.

We are much indebted to the medical staff of the Royal Victoria Hospital, to Dr T. Milliken and Dr J. Russell of the Musgrave Park Hospital and to Dr F. Stanford of the Forster Green Hospital for permission to examine their patients. We thank Mrs Margaret Clarke of the Royal Victoria Hospital secretarial staff for untiring work with the administrative arrangements. We are also indebted to the patients for their ready co-operation and to the Northern Ireland Kidney Research Fund for financial assistance with the purchasing of equipment.

\section{References}

Brewerton, D. A., Caffrey, M., Hart, F. D., James, D. C. O., Nicholls, A., and Sturrock, R. D. (1973a). Ankylosing spondylitis and HL-A 27. Lancet, 1, 904-907.

Brewerton, D. A., Caffrey, M., Nicholls, A., James, D. C. O., Oates, J. K., and Walters, D. (1973b). Reiter's disease and HL-A27. Lancet, 2, 996-998.

Buc, M., Nyulassy, S., Stefanovic, J., Michalko, J., and Mozolavá, D. (1974). HL-A system and juvenile rheumatoid arthritis. Tissue Antigens, 4, 395-397.

Carey, G. C. R., Elwood, P. C., McAulay, I. R., Merrett, J. D., and Pemberton, J. (1965). Byssinosis in Flax Workers in Northern Ireland. A report to the Ministry of Labour and National Insurance, the Government of Northern Ireland. HMSO: Belfast.

Ebringer, A., Cowling, P., Ngura Sum, N., James, D. C. O., and Ebringer, R. W. (1976). In Abstracts of the International Congress on HLA and Disease, p. 27. Editions Inserm: Paris.

Gerkins, V. R., Ting, A., Menck, H. T., Casagrande, J. T., Terasaki, P. I., Pike, M. C., and Henderson, B. E. (1974). HL-A heterozygosity as a genetic marker of long-term survival. Journal of the National Cancer Institute, 52, 19091911. 
Logan, J. S. (1959). Flax-dust byssinosis and chronic nontuberculous chest disease in Belfast. Ulster Medical Journal, 28, 164-175.

Malcolm, A. G. (1856). The influence of factory life on the health of the operative as founded upon the Medical Statistics of the Class at Belfast. Journal of the Statistical Society, 19, 170-181.

Nelson, S. D., and Middleton, D. (1975). HL-A typing in Northern Ireland. Ulster Medical Journal, 44, 48-52.

Ramazzini, B. (1705). A Treatise of the Diseases of Tradesmen, now done into English. Printed for Andrew Bell and eight other book sellers: London.

Schlosstein, L., Terasaki, P., Bluestone, R., and Pearson, C. M. (1973). High association of an HL-A antigen, W27, with ankylosing spondylitis. New England Journal of Medicine, 288, 704-706.

Smiley, J. A. (1951). The hazards of rope making. British Journal of Industrial Medicine, 8, 265-270.

Smiley, J. A. (1956). The social and industrial background of the Irish linen trade. Transactions of the Association of Industrial Medical Officers, 5, 103-108.

Svejgaard, A., Platz, P., Ryder, L. P., Nielsen, L. S., and Thomsen, M. (1975). HL-A and disease associations: a survey. Transplantation Reviews, 22, 3-43. 